\title{
Chickpea-mediated effects of Bacillus thuringiensis on Helicoverpa armigera and its larval parasitoid, Campoletis chlorideae
}

\author{
M. K. Dhillon \& H. C. Sharma \\ International Crops Research Institute for the Semi-Arid Tropics (ICRISAT), Patancheru, Andhra Pradesh, India
}

\author{
Keywords \\ Bacillus thuringiensis, Campoletis chlorideae, \\ Helicoverpa armigera, chickpea, non-target \\ effects, tritrophic interactions

\section{Correspondence} \\ Hari C. Sharma (corresponding author), \\ Principal Scientist - Entomology, ICRISAT, \\ Patancheru 502 324, Andhra Pradesh, India. \\ E-mail: h.sharma@cgiar.org \\ Received: August 5, 2009; \\ accepted: January 7, 2010
}

doi: 10.1111/j.1439-0418.2010.01506.x

\begin{abstract}
Efforts are underway to express toxin genes from Bacillus thuringiensis $(B t)$ in chickpea for controlling the pod borer, Helicoverpa armigera. The interaction between $B t$ toxins, Helicoverpa-resistant chickpeas, and the parasitoid, Campoletis chlorideae are not fully understood. Therefore, we studied tritrophic interactions between $B t$ (administered as spray), chickpea genotypes, and the parasitoid, C. chlorideae. Chickpea genotypes resistant to $H$. armigera exercised a significant reduction in leaf feeding, survival and development of $H$. armigera, but did not influence the development and survival of the parasitoid, C. chlorideae. Bt sprays on different chickpea genotypes prolonged the larval period, and reduced pupation and adult emergence of C.chlorideae. Weights of $H$. armigera larvae showed a strong and positive association with $C$. chlorideae larval period on $B t$ treated, and a negative association on untreated chickpeas. The $B t$-intoxicated $H$. armigera larvae also resulted in reduced weight of the cocoons and adults of $C$. chlorideae, suggesting significant influence of host size on development and survival of the parasitoid. Bt toxins were detected in $H$. armigera larvae fed on Bt-sprayed chickpeas, but not in $C$. chlorideae reared on $H$. armigera larvae fed on Bt-treated chickpeas, and in the parasitoid adults fed on honey intoxicated with $0.05 \% \mathrm{Bt}$. The adverse effects of $B t$ on the parasitoid were largely through early mortality of $H$. armigera larvae or poor quality of the host. This information would be useful for planning appropriate strategies for testing and deployment of $B t$-transgenic chickpea with resistance to $H$. armigera for sustainable crop production.
\end{abstract}

\section{Introduction}

Chickpea (Cicer arietinum L.) is the world's third most important food legume, grown in tropical, subtropical and temperate regions, and is the premier pulse crop in the Indian subcontinent (Hulse 1991). It is valued for its nutritive seeds with high protein content $(25.3-28.9 \%)$. Chickpea seeds are consumed fresh as a green vegetable, fried, roasted and boiled as a snack food. The grain after dehulling is largely consumed as split seeds as 'dhal', or the split seeds are ground as flour, which is used to make bread, snacks and sweets. The straw is used as feed for livestock. It is grown on about 10.38 million ha with a production of 8.57 million tonnes worldwide (FAO 2004). India is the largest producer as well as consumer of chickpea. In India, chickpea is grown on about 6.67 million ha with a production of 5.3 million tonnes (Majumder 2009). Chickpea yields are low (400-600 kg/ha), because of several biotic and abiotic constraints, of which the pod borer, Helicoverpa armigera (Hubner) (Noctuidae: Lepidoptera) is 
the most important constraint in chickpea production (Manjunath et al. 1989). In addition to chickpea, H. armigera also damages several other crops such as cereals, pulses, cotton, vegetables, fruit crops and forest trees. It causes an estimated loss of US $\$ 2$ billion annually, despite US\$500 million worth of insecticides used to control this pest worldwide (Sharma 2005).

The parasitic wasp, Campoletis chlorideae Uchida (Ichneumonidae: Hymenoptera), parasitizes several lepidopteran insect species (Yan and Wang 2006; Dhillon and Sharma 2007), and is one of the common larval parasitoids of the pod borer, $H$. armigera in chickpea (Bhatnagar et al. 1982; Kumar et al. 1994). Bacillus thuringiensis (Berliner) (Bt) has been used extensively for the management of $H$. armigera in India, China, Philippines, Malaysia and North America (Gujar 2005). It can be used in combination with conventional host-plant resistance for managing this pest. In addition to the use of $B t$ as a conventional pesticide, $B t$-transgenic crops, which constitutively produce $\delta$-endotoxins from $B t$, can be used to provide protection from insect damage throughout the crop season. Transgenic cottons with $B t$ toxin genes have been released for cultivation in several countries (James 2007), whereas transgenic chickpea with $B t$ genes expressing either CrylAc or Cry2Aa, or both proteins, are currently under development and could become commercially available for imparting resistance to $H$. armigera (Sanyal et al. 2005; Sharma et al. 2005a,b; McPhee et al. 2007). Considerable information is available on the host-mediated effects of Bt-transgenic crops on the parasitoids (Romeis et al. 2006). Although, $B t$-transgenic chickpea has been found compatible with entomopathogenic fungus, Metarhizium anisopliae for the management of $H$. armigera (Lawo et al. 2008), compatibility of Bt-chickpea with $H$. armigera larval parasitoid, $C$. chlorideae has not been tested yet, which might influence its activity and abundance in the chickpea ecosystem. The effects of $B t$ toxins on the parasitoid could be due to direct exposure to the toxins through Bt spray or Bt-contaminated chickpea leaf exudates or honeydew from aphids, and the indirect effects via reduction in host density and nutritional quality. Moreover, interaction between $B t$ toxins and chickpea genotypes with different levels of resistance to $H$. armigera, and the parasitoid, C. chlorideae; and the adverse effects of direct exposure of adult parasitoids to $B t$ toxins on longevity, fitness and fecundity are also not fully understood. Therefore, the present studies were undertaken to investigate the direct effects of $B t$ on $C$. chlorideae through Bt-contaminated honey, and indirect effects through chickpea genotypes with different levels of resistance to $H$. armigera and Bt sprays on the survival, development and fecundity of the parasitoid, C. chlorideae.

\section{Materials and Methods}

\section{Plant material}

Four chickpea genotypes (ICC 506 - resistant, ICCV 10 - moderately resistant, C 235 - moderately susceptible and L 550 - susceptible) were planted during the 2005-2006 and 2007-2008 post-rainy seasons (October-March) at the research farm of the International Crops Research Institute for the Semi-Arid Tropics (ICRISAT), Patancheru, India. Recommended agronomic practices, except insecticide sprays, were followed for raising the crop. Each genotype was planted in a four-row plot, $2 \mathrm{~m}$ long, and the rows were $60 \mathrm{~cm}$ apart. There were three replications in a randomized complete block design. The experiment was planted in two sets, on an area of $16 \mathrm{~m}^{2}$ each. The test plots were covered with a nylon net to avoid interference from other insect species, and natural infestation by $H$. armigera. One set of chickpea genotypes was sprayed with a sublethal dose $(0.05 \%)$ of Bt (Biolep ${ }^{\circ}$; Biotech International Ltd., New Delhi, India) at the flowering stage with knapsack sprayer, while the unsprayed genotypes were used as controls.

\section{Characteristics of $B t$ formulation (Biolep ${ }^{\circledR}$ )}

The Bacillus thuringiensis var. kurstaki (Serotype H-3 a, 3 b, Strain Z-52) formulation Biolep ${ }^{\circledR}$ used in the present studies, is a water dispersible powder, which acts on the host larvae through its parasporal crystal $\delta$-endotoxins and the bacterial spores. Biolep ${ }^{\circledR}$ contained 5-8\% Bt $\delta$-endotoxins, 5-8\% Bt spores, $37-55 \%$ nutrient medium residues, $15-20 \%$ sodium chloride, 15-18\%, fillers (Kaolin) and a moisture content of 5-9\%. The Bt formulation sprayed on the chickpea plants or mixed in $10 \%$ honey solution $\left[0.05 \%\right.$, i.e. $\mathrm{ED}_{75}$ (effective concentration to cause a $75 \%$ reduction in $H$. armigera larval weight)], contained $25-40 \mu \mathrm{g} / \mathrm{ml} B t \delta$-endotoxins, and $25-40 \mu \mathrm{g} / \mathrm{ml} B t$ spores. It is a mixture of CrylAa (28\%), CrylAb (53\%), CrylAc (19\%), and Cry $2 \mathrm{~A}$ and Cry $2 \mathrm{~B} \quad(<0.1 \%)$ (Chandrashekar et al. 2005). 


\section{Insect culture}

Helicoverpa armigera larvae were reared on chickpeabased semi-synthetic artificial diet under laboratory conditions at $27 \pm 2{ }^{\circ} \mathrm{C}$ and $65-85 \%$ RH (Armes et al. 1992). The $H$. armigera culture maintained in the laboratory was used for rearing the parasitoid, C. chlorideae, and for conducting the bioassays.

Cocoons of $C$. chlorideae were collected from chickpea fields at the ICRISAT research farm, Patancheru, India, and placed individually in plastic vials $(2.5 \mathrm{~cm}$ diameter $\times 7.5 \mathrm{~cm}$ height) until adult emergence. The adult wasps were released in plastic cages (15 cm diameter $\times 18.5 \mathrm{~cm}$ height) for mating, and fed ad libitum on $10 \%$ honey solution. The mating was observed visually, and the mated pairs were transferred to another cages. For oviposition, the mated females were transferred to transparent plastic vials $(2.5 \mathrm{~cm}$ diameter $\times 7.5 \mathrm{~cm}$ height $)$ kept in an inverted condition in a Petri dish $(9.5 \mathrm{~cm}$ diameter $\times 1 \mathrm{~cm}$ height). Single second-instar larvae of $H$. armigera were offered to the parasitoid females for female attack. The parasitoid females, in general, attacked the $H$. armigera larvae in 1-2 min. After female attack, the $H$. armigera larvae were removed, and placed on chickpea-based artificial diet for further development. The parasitoid culture and the bioassays were conducted at $27 \pm 2{ }^{\circ} \mathrm{C}, 65-75 \% \mathrm{RH}$ and a 12 -h photoperiod in the laboratory.

\section{Effects of Bacillus thuringiensis-treated chickpeas on Helicoverpa armigera larvae}

Host-plant-mediated effects of Bt on leaf feeding, survival and development of $H$. armigera larvae were studied on four chickpea genotypes. Terminal branches from the $B t$-sprayed (after $2 \mathrm{~h}$ of spraying) and unsprayed plants were brought to the laboratory, and 10 neonate $H$. armigera larvae were released on each branch (having four leaves and a growing tip) using detached leaf bioassay (Sharma et al. 2005a,b). There were 8 and 10 replications (number of terminal branches bioassayed for each genotype; $\mathrm{N}=18$ ) during the 2005-2006 and 2007-2008 post-rainy seasons (October-March), respectively, in a completely randomized design (CRD). After 5 days of feeding, the $B t$-sprayed and unsprayed chickpea branches were evaluated for leaf damage on a 1-9 scale ( $1 \leq 10 \%$ leaf area damaged, and $9 \geq 80 \%$ leaf area damaged). The surviving larvae were individually collected in 25-ml cups and weighed (using Mettler AE 160 balance; Mettler-Toledo Inc., Columbus, OH, USA) after $4 \mathrm{~h}$ to assess weight gain by the larvae.
Host-plant-mediated effects of Bt sprays on the larval parasitoid, Campoletis chlorideae

Host-plant-mediated effects of Bt sprays on survival and development of C. chlorideae were studied through $H$. armigera larvae fed on four Bt-sprayed/ unsprayed chickpea genotypes during the 20052006 and 2007-2008 post-rainy seasons. Neonate $H$. armigera larvae were fed on terminal branches of $B t$-sprayed and control chickpeas using the detached leaf bioassay. After 5 days of feeding on the $B t$-sprayed foliage, the $H$. armigera larvae were exposed to the $C$. chlorideae females till they attacked the host larvae, and were again fed on the $B t$-sprayed foliage of the same chickpea genotype till emergence of the parasitoid larvae from the host larvae. In the case of larvae fed on unsprayed foliage, the larvae were exposed for parasitization after 3 days, as they grew at a faster rate. Twenty-five $H$. armigera larvae were parasitized per replication, and there were three replications in a CRD in each season $(\mathrm{N}=6)$. Observations were recorded on percent parasitization, days to cocoon formation (egg + larval period), pupal period, cocoon formation and adult emergence. The weight, length and diameter of the parasitoid cocoons and weights of adult males and females were also recorded. The cocoons and adults were weighed using Mettler AE 160 balance, and the length and diameter of the cocoons was recorded using vernier calipers. Live parasitoid adults were weighed within $24 \mathrm{~h}$ of emergence. The parasitoid adults were collected individually in the plastic vials with the help of a specially designed aspirator, to avoid escape during the weighing. Fecundity (equivalent to number of stabbings/ female; Dhillon and Sharma 2009b) of C. chlorideae females emerging from the larvae fed on Bt-treated and untreated chickpea genotypes was recorded for five pairs $(\mathrm{N}=5)$, and the carry-over effects of $B t$ and/or chickpea genotypes on the parasitoid survival and development were studied by rearing their progenies on the $H$. armigera larvae fed on control artificial diet at $27 \pm 2{ }^{\circ} \mathrm{C}, 65-75 \% \mathrm{RH}$, and a $12-\mathrm{h}$ photoperiod in the laboratory.

\section{Direct effects of Bt on Campoletis chlorideae adults}

The direct effects of Bt (Bt was mixed at $0.05 \%$ in $10 \%$ honey solution) were assessed on the male and female longevity and fecundity, and on cocoon formation and adult emergence of the progenies through Bt-contaminated 10\% honey solution fed to the adults of $C$. chlorideae. The honey solution was 
changed on alternate days. The adults fed on uncontaminated $10 \%$ honey were used as controls. Six adult males and females were used per treatment in this experiment, thus making six replications $(\mathrm{N}=6)$ in a CRD. The experiment was conducted under laboratory conditions at $27 \pm 2^{\circ} \mathrm{C}, 65-75 \% \mathrm{RH}$, and a 12-h photoperiod.

Detection of Bt toxins in Helicoverpa armigera and Campoletis chlorideae

Helicoverpa armigera larvae fed on Bt-sprayed and unsprayed chickpea plants, and larvae, pupae, and adults of $C$. chlorideae reared on $H$. armigera larvae fed on Bt-sprayed and unsprayed plants, as well as the C.chlorideae adults fed on Bt-contaminated honey were subjected to a semi-quantitative ELISA test (Agdia ${ }^{\circledR}$, Inc., Elkhart, IN, USA) for detection of CrylAb and CrylAc Bt toxins. However, other Bt toxins present in the $B t$ formulation Biolep ${ }^{\circledR}$ could not be detected/assessed through ELISA kit as we were not having access to antibodies for CrylAa, Cry2A and Cry2B. These toxins though present in very small amounts (except Cry $1 \mathrm{Aa}$ ), may be taken into consideration while doing such bioassays. Helicoverpa armigera larvae fed on Bt-sprayed chickpeas and the C.chlorideae adults fed on Bt-contaminated honey were washed thoroughly with PBS buffer to avoid $B t$ contamination of the insect samples through contact with their food. Campoletis chlorideae larvae were collected from parasitized $H$. armigera larvae when the parasitoid larvae were ready to emerge from the host larvae for pupation. In each replication, 8-10 H. armigera larvae/different life stages of the parasitoid were collected in separate Eppendorf tubes and crushed in PBS buffer in the ratio of $1: 10$ (insect sample: buffer). The ELISA test was performed for each sample as reported by Sharma et al. (2008).

\section{Statistical analysis}

The data were subjected to normality and homogeneity tests, and the seasonal effects were found to be non-significant. Thus, data from both the seasons were pooled for analysis of variance (ANOVA) using GenStat 10th version (GenStat 2008) in a factorial design to test the effects of genotypes, Bt sprays, and the interaction effects of genotypes $\times B t$ sprays on different life stage parameters of C. chlorideae. The significance of differences between the treatments and their interaction effects were judged by $F$-test, while the treatment mean values were compared by least significant difference (LSD) at $\mathrm{P} \leq 0.05$. Association between size of the host, $H$. armigera larvae and parasitoid performance on different chickpea genotypes under $B t$-sprayed and unsprayed conditions were analysed using scatter plots showing regression lines.

\section{Results}

Effect of chickpea genotypes and Bt sprays on leaf feeding, and survival and development of Helicoverpa armigera

Survival of $H$. armigera larvae was significantly influenced by both $B t$ spray $\left(F_{1,17}=165.41, \mathrm{P}<0.001\right)$ and the chickpea genotypes $\left(F_{3,51}=2.78, \mathrm{P}=0.04\right)$, but the interaction effects were non-significant. However, the interaction effects of $B t$ sprays $\times$ chickpea genotypes for leaf damage $\left(F_{3,51}=8.48\right.$, $\mathrm{P}<0.001)$ and larval weight $\left(F_{3,51}=6.70\right.$, $\mathrm{P}<0.001$ ) were significant. Foliar damage by $H$. armigera, and the larval survival and weights were significantly lower on $B t$-sprayed plants than on the unsprayed plants (table 1). Leaf damage, and larval survival and weights were significantly greater on $\mathrm{L}$ 550 (susceptible) than that on ICC 506 (resistant) under untreated conditions. However, these genotypic effects were not apparent when the plants were sprayed with $B t$.

Host-mediated effects of Bt sprays on Campoletis chlorideae

The parasitoid, C. chlorideae larval period was significantly prolonged $\left(F_{1,5}=72.38, \mathrm{P}<0.001\right)$ in insects reared on $H$. armigera larvae fed on $B t$-treated chickpeas as compared to the untreated controls (table 2). The larval period of $C$. chlorideae in Bt-treated chickpeas fed $H$. armigera larvae was prolonged by $<1$ day. Cocoon formation $\left(F_{1,5}=403.86, \quad \mathrm{P}<0.001\right)$ and adult emergence $\left(F_{1,5}=421.54, \mathrm{P}<0.001\right)$ were significantly lower in $C$. chlorideae reared on $H$. armigera larvae fed on Bt-treated chickpeas as compared to those fed on untreated controls (table 2). There were no significant effects of Bt sprays or genotypes on the pupal period of C. chlorideae. Helicoverpa armigera larvae fed on Bt-sprayed chickpeas reduced cocoon formation (by $42.6-56.0 \%$ ), and adult emergence (by $40.0-52.0 \%$ ) of C. chlorideae over the untreated controls (table 2). There were no significant effects of chickpea genotypes on the development period, cocoon formation and adult emergence of C. chlorideae. 
Table 1 Host-plant-mediated effects of Bacillus thuringiensis on leaf feeding, and survival and development of Helicoverpa armigera

\begin{tabular}{|c|c|c|c|c|c|c|c|c|c|}
\hline \multirow[b]{2}{*}{$\begin{array}{l}\text { Chickpea } \\
\text { genotypes }\end{array}$} & \multicolumn{3}{|c|}{ Damage rating $^{1}$} & \multicolumn{3}{|c|}{ Larval survival (\%) } & \multicolumn{3}{|c|}{ Larval weight (mg/larva) } \\
\hline & $\begin{array}{l}\text { Bt } \\
\text { sprayed }\end{array}$ & $\begin{array}{l}\text { Untreated } \\
\text { control }\end{array}$ & Mean & $\begin{array}{l}\text { Bt } \\
\text { sprayed }\end{array}$ & $\begin{array}{l}\text { Untreated } \\
\text { control }\end{array}$ & Mean & $\begin{array}{l}\text { Bt } \\
\text { sprayed }\end{array}$ & $\begin{array}{l}\text { Untreated } \\
\text { control }\end{array}$ & Mean \\
\hline L 550 & $1.9 \mathrm{a}$ & $6.6 \mathrm{~b}$ & 4.2 & $27.2 \mathrm{a}$ & $78.9 \mathrm{~b}$ & 53.1 & $1.25 \mathrm{a}$ & $5.10 \mathrm{~b}$ & 3.17 \\
\hline C 235 & $2.5 \mathrm{a}$ & $5.2 \mathrm{~b}$ & 3.9 & $35.6 \mathrm{a}$ & $71.1 \mathrm{~b}$ & 53.3 & $1.31 \mathrm{a}$ & $5.61 \mathrm{~b}$ & 3.46 \\
\hline ICCV 10 & $2.3 \mathrm{a}$ & $5.2 \mathrm{~b}$ & 3.7 & 26.7 a & $66.1 \mathrm{~b}$ & 46.4 & $1.43 \mathrm{a}$ & $5.54 \mathrm{~b}$ & 3.48 \\
\hline ICC 506 & $1.7 \mathrm{a}$ & $3.4 \mathrm{~b}$ & 2.5 & $26.1 \mathrm{a}$ & 59.4 b & 42.8 & $1.34 \mathrm{a}$ & $3.65 \mathrm{~b}$ & 2.49 \\
\hline Mean & 2.1 & 5.1 & - & 28.9 & 68.9 & - & 1.3 & 5.0 & - \\
\hline For comparing & $\mathrm{SE} \pm$ & LSD $(P \leq 0$ & & $\mathrm{SE} \pm$ & LSD $(P \leq 0$ & & $\mathrm{SE} \pm$ & LSD $(P \leq 0.05)$ & \\
\hline Genotype (G) & 0.21 & $0.60 * *$ & & 3.11 & $8.71 *$ & & 0.18 & $0.49 * *$ & \\
\hline Bt spray $(\mathrm{T})$ & 0.15 & $0.43^{* *}$ & & 2.20 & $6.16^{\star *}$ & & 0.12 & $0.35^{\star \star}$ & \\
\hline$G \times T$ & 0.30 & $0.85^{\star \star}$ & & 4.40 & NS & & 0.25 & $0.70 * *$ & \\
\hline
\end{tabular}

*, **, Significant at $P \leq 0.05$ and 0.01 , respectively. NS, non-significant at $P \leq 0.05$.

${ }^{1}$ Damage rating ( $1 \leq 10 \%$ leaves were damaged, and $9 \geq 80 \%$ leaves were damaged). The values for Bt sprayed and untreated controls for a genotype under each parameter following different letters are significant at $\mathrm{P} \leq 0.05$.

Table 2 Effect of Bacillus thuringiensis-treated chickpea fed to Helicoverpa armigera larvae on the survival and development of Campoletis chlorideae in the first generation

\begin{tabular}{|c|c|c|c|c|c|c|c|c|c|c|c|c|}
\hline \multirow[b]{2}{*}{$\begin{array}{l}\text { Chickpea } \\
\text { genotypes }\end{array}$} & \multicolumn{3}{|c|}{ Larval period (days) } & \multicolumn{3}{|c|}{ Pupal period (days) } & \multicolumn{3}{|c|}{ Cocoon formation (\%) } & \multicolumn{3}{|c|}{ Adult emergence (\%) } \\
\hline & $\begin{array}{l}\text { Bt } \\
\text { sprayed }\end{array}$ & $\begin{array}{l}\text { Untreated } \\
\text { control }\end{array}$ & Mean & $\begin{array}{l}\text { Bt } \\
\text { sprayed }\end{array}$ & $\begin{array}{l}\text { Untreated } \\
\text { control }\end{array}$ & Mean & $\begin{array}{l}\text { Bt } \\
\text { sprayed }\end{array}$ & $\begin{array}{l}\text { Untreated } \\
\text { control }\end{array}$ & Mean & $\begin{array}{l}\text { Bt } \\
\text { sprayed }\end{array}$ & $\begin{array}{l}\text { Untreated } \\
\text { control }\end{array}$ & Mean \\
\hline L 550 & $7.6 \mathrm{~b}$ & $7.1 \mathrm{a}$ & 7.3 & $5.8 \mathrm{a}$ & $5.6 \mathrm{a}$ & 5.7 & 26.7 a & $69.3 \mathrm{~b}$ & 48.0 & $16.0 \mathrm{a}$ & $56.0 \mathrm{~b}$ & 36.0 \\
\hline C 235 & $7.7 \mathrm{~b}$ & $7.0 \mathrm{a}$ & 7.4 & $5.7 \mathrm{a}$ & $5.7 \mathrm{a}$ & 5.7 & $22.0 \mathrm{a}$ & $74.7 \mathrm{~b}$ & 48.3 & $15.3 \mathrm{a}$ & $55.3 \mathrm{~b}$ & 35.3 \\
\hline ICCV 10 & $8.0 \mathrm{~b}$ & $7.1 \mathrm{a}$ & 7.6 & $5.5 \mathrm{a}$ & $5.6 \mathrm{a}$ & 5.6 & 22.7 a & $78.7 \mathrm{~b}$ & 50.7 & $14.0 \mathrm{a}$ & $60.0 \mathrm{~b}$ & 37.0 \\
\hline ICC 506 & $7.8 \mathrm{~b}$ & $7.2 \mathrm{a}$ & 7.5 & $5.9 \mathrm{a}$ & $5.7 \mathrm{a}$ & 5.8 & $28.0 \mathrm{a}$ & $75.3 b$ & 51.7 & 14.0 a & $66.0 \mathrm{~b}$ & 40.0 \\
\hline Mean & 7.8 & 7.1 & - & 5.7 & 5.7 & - & 24.8 & 74.5 & - & 14.8 & 59.3 & - \\
\hline For comparing & $\mathrm{SE} \pm$ & LSD $(P \leq 0$. & & $\mathrm{SE} \pm$ & LSD $(P \leq 0$ & & $\mathrm{SE} \pm$ & LSD $(P \leq 0$ & & $\mathrm{SE} \pm$ & LSD $(\mathrm{P} \leq 0$ & \\
\hline Genotype (G) & 0.08 & NS & & 0.06 & NS & & 2.47 & NS & & 2.17 & NS & \\
\hline Bt spray (T) & 0.06 & $0.17 \star \star$ & & 0.04 & NS & & 1.75 & $5.02 * \star$ & & 1.53 & $4.40 * \star$ & \\
\hline$G \times T$ & 0.12 & NS & & 0.09 & NS & & 3.50 & NS & & 3.07 & NS & \\
\hline
\end{tabular}

*, **, Significant at $\mathrm{P} \leq 0.05$ and 0.01 , respectively. NS, non-significant at $\mathrm{P} \leq 0.05$. The values for Bt sprayed and untreated controls for a genotype under each parameter following different letters are significant at $P \leq 0.05$.

\section{Host-plant-mediated effects of $B t$ on morphological traits of Campoletis chlorideae}

The effects of chickpea genotypes and $B t$ sprays were significant on cocoon weight (genotypes: $F_{3,15}=5.26$, $\mathrm{P}=0.004 ; B t$ sprays: $\left.F_{3,15}=223.5, \mathrm{P}<0.001\right)$, length (genotypes: $\quad F_{3,15}=9.25, \quad \mathrm{P}<0.001 ; \quad B t$ sprays: $F_{3,15}=176.66, \mathrm{P}<0.001$ ) and diameter (genotypes: $F_{3,15}=4.21, \quad \mathrm{P}=0.012 ; \quad$ Bt sprays: $F_{3,15}=63.91$, $\mathrm{P}<0.001$ ) of the parasitoid, C. chlorideae. However, the interaction effects of chickpea genotypes $\times B t$ sprays on these cocoon characteristics were non-significant at $\mathrm{P}=0.05$. Cocoon weight, length, and diameter of the parasitoid were significantly reduced when reared on $H$. armigera larvae fed on the resistant genotype, ICC 506 (table 3). The cocoons weighed lower (7.11 vs. $10.06 \mathrm{mg} /$ cocoon), and were smaller in length (4.98 vs. $5.89 \mathrm{~mm})$ and breadth (2.59 vs. $2.97 \mathrm{~mm}$ ) when reared on Bt-sprayed chickpea-fed $H$. armigera larvae as compared to the ones reared on untreated chickpeas (table 3).

The interaction effects of $B t$ sprays $\times$ chickpea genotypes on male parasitoid body weight $\left(F_{3,12}=6.78, \mathrm{P}=0.001\right)$ and longevity $\left(F_{3,12}=3.03\right.$, $\mathrm{P}=0.048$ ) were significant. The $B t$ sprays also reduced the weight of $C$. chlorideae females significantly $\left(F_{1,4}=40.38, \quad \mathrm{P}<0.001\right)$. The males and females obtained from $H$. armigera larvae fed on 
Table 3 Effects of Bacillus thuringiensis-treated chickpea fed to Helicoverpa armigera larvae on the size and weight of Campoletis chlorideae cocoons

\begin{tabular}{|c|c|c|c|c|c|c|c|c|c|}
\hline \multirow[b]{2}{*}{$\begin{array}{l}\text { Chickpea } \\
\text { genotypes }\end{array}$} & \multicolumn{3}{|c|}{ Weight (mg) } & \multicolumn{3}{|c|}{ Length (mm) } & \multicolumn{3}{|c|}{ Diameter $(\mathrm{mm})$} \\
\hline & $\begin{array}{l}\text { Bt } \\
\text { sprayed }\end{array}$ & $\begin{array}{l}\text { Untreated } \\
\text { control }\end{array}$ & Mean & $\begin{array}{l}\text { Bt } \\
\text { sprayed }\end{array}$ & $\begin{array}{l}\text { Untreated } \\
\text { control }\end{array}$ & Mean & $\begin{array}{l}\text { Bt } \\
\text { sprayed }\end{array}$ & $\begin{array}{l}\text { Untreated } \\
\text { control }\end{array}$ & Mean \\
\hline L 550 & $7.73 \mathrm{a}$ & $9.83 \mathrm{~b}$ & 8.78 & $5.07 \mathrm{a}$ & $6.00 \mathrm{~b}$ & 5.53 & $2.57 \mathrm{a}$ & $3.00 \mathrm{~b}$ & 2.78 \\
\hline C 235 & $7.01 \mathrm{a}$ & $10.63 b$ & 8.82 & $5.21 \mathrm{a}$ & $6.03 \mathrm{~b}$ & 5.62 & $2.79 \mathrm{a}$ & $3.01 \mathrm{~b}$ & 2.90 \\
\hline ICCV 10 & $7.24 \mathrm{a}$ & $10.41 \mathrm{~b}$ & 8.83 & $4.91 \mathrm{a}$ & $6.01 \mathrm{~b}$ & 5.46 & $2.53 \mathrm{a}$ & $3.01 \mathrm{~b}$ & 2.77 \\
\hline ICC 506 & $6.46 \mathrm{a}$ & $9.36 \mathrm{~b}$ & 7.91 & $4.75 \mathrm{a}$ & $5.54 \mathrm{~b}$ & 5.14 & $2.46 \mathrm{a}$ & $2.86 \mathrm{~b}$ & 2.66 \\
\hline Mean & 7.11 & 10.06 & - & 4.98 & 5.89 & - & 2.59 & 2.97 & - \\
\hline For comparing & $\mathrm{SE} \pm$ & LSD $(P \leq 0$ & & $\mathrm{SE} \pm$ & LSD $(P \leq C$ & & $\mathrm{SE} \pm$ & LSD $(P \leq 0.05)$ & \\
\hline Genotype (G) & 0.20 & $0.57^{*}$ & & 0.07 & $0.20 * *$ & & 0.05 & $0.14^{*}$ & \\
\hline Bt spray (T) & 0.14 & $0.40^{\star *}$ & & 0.05 & $0.14^{\star *}$ & & 0.03 & $0.10^{* *}$ & \\
\hline$G \times T$ & 0.28 & NS & & 0.10 & NS & & 0.07 & NS & \\
\hline
\end{tabular}

${ }^{*},{ }^{* *}$, Significant at $P \leq 0.05$ and 0.01 , respectively. NS, non-significant at $P \leq 0.05$. The values for Bt sprayed and untreated controls for a genotype under each parameter following different letters are significant at $\mathrm{P} \leq 0.05$.

Table 4 Effects of Helicoverpa armigera larvae fed on Bacillus thuringiensis-treated chickpea on the longevity and weight of Campoletis chlorideae adults

\begin{tabular}{|c|c|c|c|c|c|c|}
\hline \multirow[b]{2}{*}{$\begin{array}{l}\text { Chickpea } \\
\text { genotypes }\end{array}$} & \multicolumn{3}{|c|}{ Longevity (days) } & \multicolumn{3}{|c|}{ Weight (mg) } \\
\hline & $\begin{array}{l}\text { Bt } \\
\text { sprayed }\end{array}$ & $\begin{array}{l}\text { Untreated } \\
\text { control }\end{array}$ & Mean & $\begin{array}{l}\text { Bt } \\
\text { sprayed }\end{array}$ & $\begin{array}{l}\text { Untreated } \\
\text { control }\end{array}$ & Mean \\
\hline \multicolumn{7}{|l|}{ Male } \\
\hline L 550 & $10.8 \mathrm{a}$ & $12.0 \mathrm{a}$ & 11.4 & $2.45 \mathrm{a}$ & $2.78 \mathrm{~b}$ & 2.61 \\
\hline C 235 & $16.8 \mathrm{a}$ & $13.3 \mathrm{a}$ & 15.1 & $2.18 \mathrm{a}$ & $3.03 \mathrm{~b}$ & 2.60 \\
\hline ICCV 10 & $12.6 \mathrm{a}$ & $12.8 \mathrm{a}$ & 12.7 & $1.38 \mathrm{a}$ & $2.95 \mathrm{~b}$ & 2.16 \\
\hline ICC 506 & $11.2 \mathrm{a}$ & $14.3 \mathrm{a}$ & 12.8 & $1.68 \mathrm{a}$ & $2.49 \mathrm{~b}$ & 2.09 \\
\hline Mean & 12.9 & 13.1 & - & 1.92 & 2.81 & - \\
\hline For comparing & $\mathrm{SE} \pm$ & LSD $(P \leq 0$ & & $\mathrm{SE} \pm$ & LSD $(P \leq 0.05)$ & \\
\hline Genotype (G) & 0.80 & $2.33^{*}$ & & 0.10 & $0.28 * \star$ & \\
\hline Bt spray $(\mathrm{T})$ & 0.57 & NS & & 0.07 & $0.20 * \star$ & \\
\hline $\mathrm{G} \times \mathrm{T}$ & 1.13 & $3.29 *$ & & 0.14 & $0.40 *$ & \\
\hline \multicolumn{7}{|l|}{ Female } \\
\hline L 550 & $17.0 \mathrm{a}$ & $16.0 \mathrm{a}$ & 16.5 & $2.54 \mathrm{a}$ & $3.53 b$ & 3.04 \\
\hline C 235 & $15.7 \mathrm{a}$ & 18.8 a & 17.3 & $2.27 a$ & $3.29 b$ & 2.78 \\
\hline ICCV 10 & $17.0 \mathrm{a}$ & 15.9 a & 16.5 & $2.06 a$ & $3.53 \mathrm{~b}$ & 2.80 \\
\hline ICC 506 & $17.2 \mathrm{a}$ & 18.9 a & 18.1 & $2.66 \mathrm{a}$ & $3.20 \mathrm{~b}$ & 2.93 \\
\hline Mean & 16.7 & 17.4 & - & 2.38 & 3.39 & - \\
\hline For comparing & $\mathrm{SE} \pm$ & LSD $(P \leq 0$ & & SE \pm & LSD $(P \leq 0.05)$ & \\
\hline Genotype (G) & 0.85 & NS & & 0.16 & NS & \\
\hline Bt spray (T) & 0.60 & NS & & 0.11 & $0.32^{\star \star}$ & \\
\hline$G \times T$ & 1.21 & NS & & 0.22 & NS & \\
\hline
\end{tabular}

*, **, Significant at $\mathrm{P} \leq 0.05$ and 0.01 , respectively. NS, non-significant at $\mathrm{P} \leq 0.05$. The values for $B t$ sprayed and untreated controls for a genotype under each parameter following different letters are significant at $P \leq 0.05$.

unsprayed chickpeas were heavier $(2.81 \mathrm{mg} / \mathrm{male}$ and $3.39 \mathrm{mg} /$ female) than those obtained from Bt-sprayed chickpeas $(1.92 \mathrm{mg} / \mathrm{male}$ and $2.38 \mathrm{mg} /$ female) (table 4). However, the effects of Bt sprays on the longevity of parasitoid males and females were not significant.

The scatter plots showed a significant and positive association between $H$. armigera larval weights 
(1.1a)
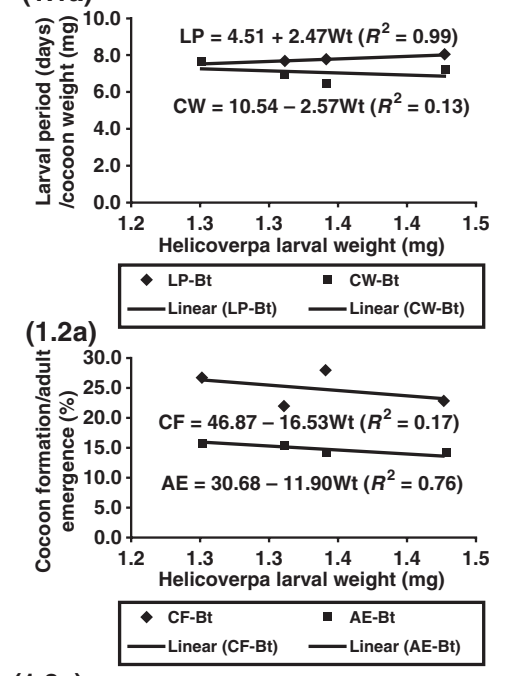

$(1.3 a)_{6.0}$
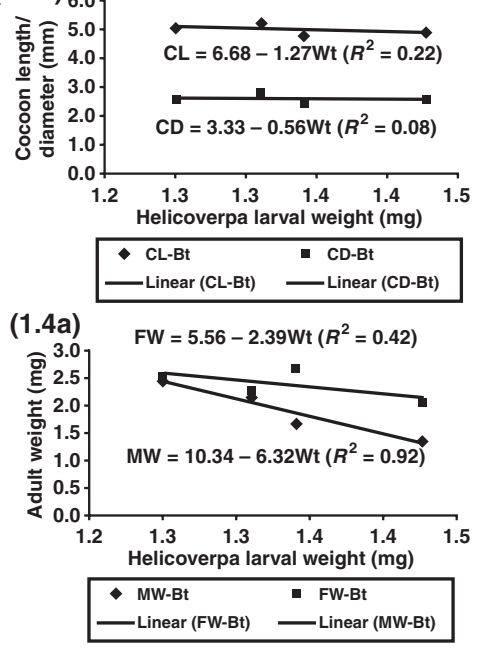

(1.1b)

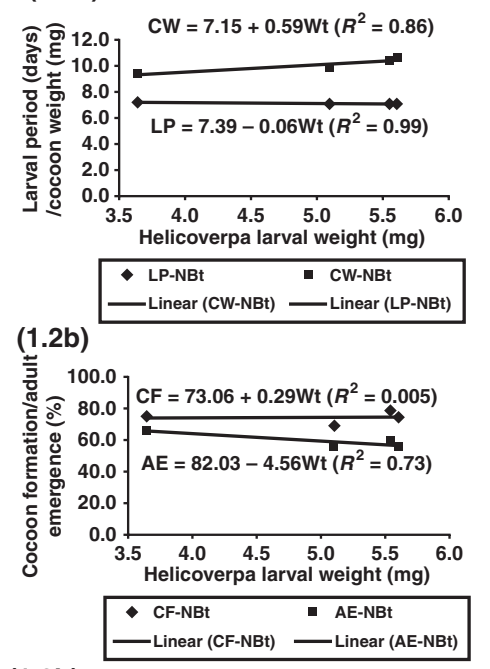

(1.3b)

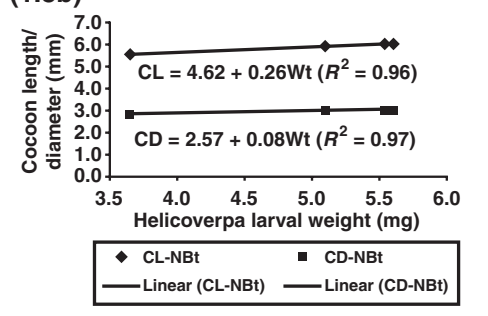

(1.4b)

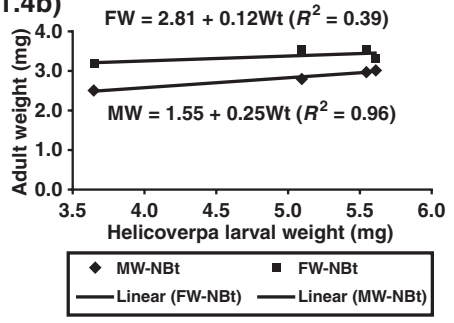

Fig. 1 Scatter plots showing regression equations of Campoletis chlorideae larval period (LP) and cocoon weight (CW) (1.1a, 1.1b), cocoon formation (CF) and adult emergence (AE) (1.2a, 1.2b), cocoon length (CL) and diameter (CD) (1.3a, 1.3b), and adult male (MW) and female (FW) weights (1.4a, 1.4b) with respect to Helicoverpa armigera larval weights (WT) in Bacillus thuringiensis-sprayed (BT) and unsprayed (NBT) chickpea genotypes, respectively. and C. chlorideae larval period on Bt-treated chickpeas (fig. 1.la), whereas a negative association was observed on untreated chickpeas (fig. 1.1b). However, reverse was the trend for cocoon weights with significant association under unsprayed and weak association under Bt-sprayed conditions, as the range in host larval weights was very narrow (1.3-1.5 mg) on Bt-sprayed chickpeas (figs. 1.1a,b). Cocoon formation was not influenced by the size of the $H$. armigera larvae on different chickpea genotypes with and without Bt treatment, but adult emergence was significantly and negatively influenced by the weight of insect host larvae (fig. 1.2a,b). The cocoon length and diameter were not significantly influenced by the size of $H$. armigera larvae on chickpeas treated with Bt (fig. 1.3a), but a positive effect of the host, $H$. armigera larvae was observed on cocoon size under unsprayed con- ditions (fig. 1.3b). The parasitoid female adult weights were poorly associated with the weight of the $H$. armigera larvae, but a significant and negative association was observed between male adult weights and the weights of $H$. armigera larvae under Bt treated (fig. 1.4a), whereas positively associated under untreated conditions (fig. 1.4b). This may be because of smaller size of the males, which may render them more sensitive to changes in host larvae.

Carry-over effects of Bt sprays on the Campoletis chlorideae in the next generation

The interaction between chickpea genotypes $\times B t$ spray showed a significant influence on cocoon formation $\left(F_{3,12}=7.26, \quad \mathrm{P}=0.001\right)$ and adult emergence $\left(F_{3,12}=9.85, \quad \mathrm{P}<0.001\right)$ in the following 
Table 5 Influence of Bacillus thuringiensis-treated chickpea fed to Helicoverpa armigera larvae on the survival and development of Campoletis chlorideae in the second generation

\begin{tabular}{|c|c|c|c|c|c|c|c|c|c|c|c|c|}
\hline \multirow[b]{2}{*}{$\begin{array}{l}\text { Chickpea } \\
\text { genotypes }\end{array}$} & \multicolumn{3}{|c|}{ Cocoon formation (\%) } & \multicolumn{3}{|c|}{ Adult emergence (\%) } & \multicolumn{3}{|c|}{ Fecundity/female } & \multicolumn{3}{|c|}{ Sex ratio $(M: F)$} \\
\hline & $\begin{array}{l}\text { Bt } \\
\text { sprayed }\end{array}$ & $\begin{array}{l}\text { Untreated } \\
\text { control }\end{array}$ & Mean & $\begin{array}{l}\text { Bt } \\
\text { sprayed }\end{array}$ & $\begin{array}{l}\text { Untreated } \\
\text { control }\end{array}$ & Mean & $\begin{array}{l}\text { Bt } \\
\text { sprayed }\end{array}$ & $\begin{array}{l}\text { Untreated } \\
\text { control }\end{array}$ & Mean & $\begin{array}{l}\text { Bt } \\
\text { sprayed }\end{array}$ & $\begin{array}{l}\text { Untreated } \\
\text { control }\end{array}$ & Mean \\
\hline L 550 & $55.6 \mathrm{a}$ & $63.0 \mathrm{~b}$ & 59.3 & $45.1 \mathrm{a}$ & $51.0 \mathrm{~b}$ & 48.0 & $140.6 \mathrm{~b}$ & $108.5 \mathrm{a}$ & 124.6 & $0.89 a$ & $0.68 \mathrm{a}$ & 0.78 \\
\hline C 235 & $82.6 \mathrm{~b}$ & $72.7 \mathrm{a}$ & 77.7 & $69.6 \mathrm{~b}$ & $58.9 \mathrm{a}$ & 64.2 & 126.6 a & 128.6 a & 127.6 & $0.64 a$ & $0.90 \mathrm{a}$ & 0.77 \\
\hline ICCV 10 & $78.0 \mathrm{~b}$ & $64.9 \mathrm{a}$ & 71.5 & $68.7 \mathrm{~b}$ & $49.3 \mathrm{a}$ & 59.0 & $141.0 \mathrm{~b}$ & $109.3 \mathrm{a}$ & 125.2 & $0.67 a$ & $0.60 \mathrm{a}$ & 0.63 \\
\hline ICC 506 & $66.4 \mathrm{a}$ & $64.9 \mathrm{a}$ & 65.7 & 54.7 a & $54.8 \mathrm{a}$ & 54.8 & $143.0 \mathrm{a}$ & 126.4 a & 134.7 & $0.71 \mathrm{a}$ & $0.85 a$ & 0.78 \\
\hline Mean & 70.7 & 66.4 & - & 59.5 & 53.5 & - & 137.8 & 118.2 & - & 0.73 & 0.75 & - \\
\hline For comparing & $\mathrm{SE} \pm$ & \multicolumn{2}{|c|}{ LSD $(P \leq 0.05)$} & $\mathrm{SE} \pm$ & \multicolumn{2}{|c|}{$\operatorname{LSD}(P \leq 0.05)$} & $\mathrm{SE} \pm$ & \multicolumn{2}{|c|}{$\operatorname{LSD}(P \leq 0.05)$} & $\mathrm{SE} \pm$ & \multicolumn{2}{|c|}{ LSD $(P \leq 0.05)$} \\
\hline Genotype (G) & 1.70 & $4.96 * *$ & & 1.79 & $5.21^{\star \star}$ & & 9.46 & NS & & 0.14 & NS & \\
\hline Bt spray $(\mathrm{T})$ & 1.20 & $3.51 *$ & & 1.27 & $3.68^{\star}$ & & 6.69 & $19.49 *$ & & 0.10 & NS & \\
\hline$G \times T$ & 2.41 & $7.01^{* *}$ & & 2.53 & $7.37 * *$ & & 13.38 & NS & & 0.20 & NS & \\
\hline
\end{tabular}

${ }^{*},{ }^{* *}$, Significant at $P \leq 0.05$ and 0.01 , respectively. NS, non-significant at $P \leq 0.05$. The values for Bt sprayed and untreated controls for a genotype under each parameter following different letters are significant at $P \leq 0.05$.

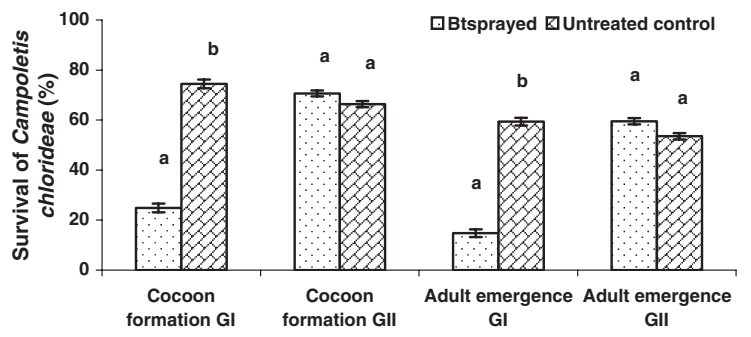

Fig. 2 Effect of Bacillus thuringiensis sprays on chickpea, via the host Helicoverpa armigera, on survival and progeny production of Campoletis chlorideae for two generations (GI, Generation I; GII, Generation II).

generation (table 5; fig. 2). Cocoon formation and adult emergence in C. chlorideae parasitizing $\mathrm{H}$. armigera fed on Bt-treated ICCV 10 and C 235 was greater than that on ICC 506 and L 550 (table 5). Fecundity of C. chlorideae females obtained from $B t$-treated chickpea-fed H. armigera (137.8 stabbings/ female) was significantly greater than those reared on the untreated chickpeas (118.2 stabbings/female) $\left(F_{1,4}=4.29, \mathrm{P}=0.049\right)$. There were no significant effects of chickpea genotypes on the fecundity of C. chlorideae females in the second generation (table 5).

\section{Direct effects of Bt on Campoletis chlorideae adults}

Direct exposure of the parasitoid adults to $B t$ in $10 \%$ honey significantly reduced the male $\left(F_{1,5}=8.60\right.$, $\mathrm{P}=0.033)$ and female $\left(F_{1,5}=18.89, \mathrm{P}=0.007\right)$ longevity, and fecundity $\left(F_{1,5}=8.04, \mathrm{P}=0.036\right)$. The $B t$-treated honey reduced male and female longevity
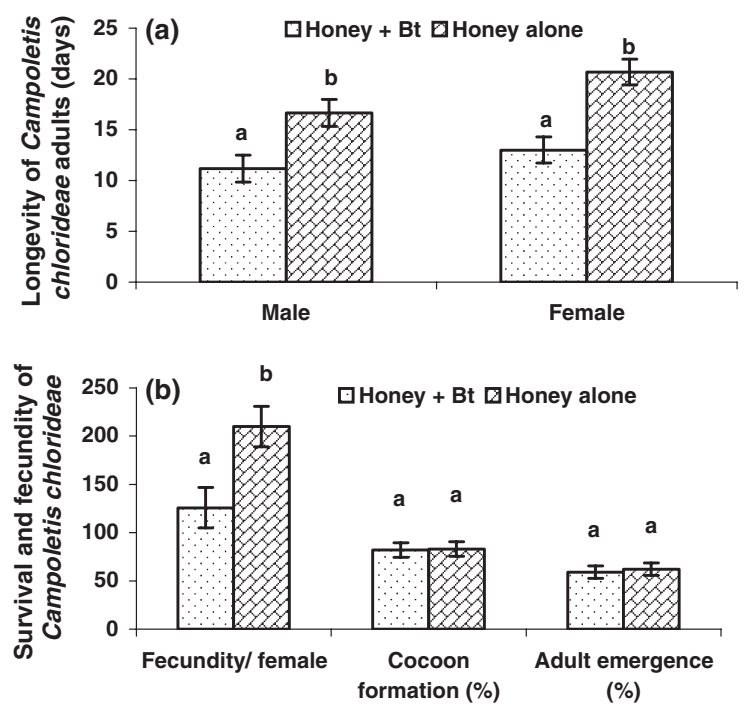

Fig. 3 Effects of Bacillus thuringiensis in honey solution fed to adults of Campoletis chlorideae on their longevity (a), and survival and fecundity (b).

by 5.5 and 7.7 days, respectively (fig. 3a), and fecundity by $40.0 \%$ (fig. 3b). However, there were no significant effects of $B t$ on cocoon formation and adult emergence of the progeny (fig. 3b).

Presence of $B t$ toxins in insect host and the parasitoid

The ELISA test detected $>5 \mathrm{ppb}$ of $B t$ toxins in $B t$-sprayed chickpea genotypes, and the $H$. armigera larvae fed on them. However, no Bt toxins were detected in the larvae, cocoons and adults of 
C. chlorideae reared on Bt-intoxicated $H$. armigera larvae, or in adult parasitoids fed on Bt-contaminated honey.

\section{Discussion}

Insect-host-plant interactions are critical in determining the effectiveness of natural enemies for biological control of insect pests. Synergism between host-plant resistance and biological control is an important phenomenon for developing practical and effective strategies for pest management. Spraying $B t$ onto resistant as well as susceptible chickpea genotypes significantly reduced the survival of, and damage by $H$. armigera larvae as compared to that on the unsprayed controls, suggesting that resistant genotypes are compatible with $B t$ sprays for the management of $H$. armigera. In certain cases, the secondary metabolites that impart resistance to insects are compatible with the natural enemies (Starks et al. 1972; Starks and Burton 1977; Barbosa et al. 1986). Campoletis sonorensis (Cameron) females attack early instars of Helicoverpa virescens (Fab.), but do not attack the bigger larvae. Therefore, under a low level of antibiosis in moderately resistant plants, the larvae of $H$. virescens remain in early instars for longer periods and are likely to be parasitized more than those feeding on susceptible plants (Danks et al. 1979). However, changes in host suitability due to the insect host's diet are also known to influence the developmental rate, size, sex ratio, fecundity, and life span of $C$. sonorensis (Vinson and Barbosa 1987). The present studies indicated that the size of $H$. armigera larvae had a significant influence on the development period, and size and survival of C. chlorideae. Although, the Helicoverpa-resistant chickpea genotype ICC 506 reduced the size of the parasitoid cocoons as compared to susceptible genotype L 550, there was no significant effect of chickpea genotypes on larval and pupal periods, and survival of the parasitoid, suggesting that the Helicoverpa-resistant chickpea genotypes are compatible with the larval parasitoid, C. chlorideae. The developmental period of C. chlorideae was prolonged, and cocoon formation and adult emergence reduced in $H$. armigera fed on $B t$-treated chickpeas as compared to those fed on untreated controls. Therefore, growing Helicoverparesistant chickpea, augmentation of $C$. chlorideae population at the vegetative growth stage (when the activity of this parasitoid is at maximum), followed by $B t$ sprays at the reproductive stage, could be sustainable option for the management of pod borer, $H$. armigera in chickpea.
Interaction of transgenic plants with non-target insects and natural enemies has been studied by several workers (Wilson et al. 1992; Fitt 2003; Romeis et al. 2006; Sharma et al. 2007; Dhillon and Sharma 2009a). Of the non-target insects, generalist predators may be relatively less affected by the transgenic plants as they tend to feed on prey, which may or may not imbibe the transgene product from the prey. On the other hand, host-specific endoparasitoids are likely to get exposed to the transgene product through insect host feeding on the transgenic plants (Vojtech et al. 2005; Ramirez-Romero et al. 2008). However, no adverse effects of transgenic maize have been observed in case of Eriborus terebrans (Gravenhorst) and Macrocentrus grandii (Goidanich) parasitizing European corn borer, Ostrinia nubilalis (Hubner) (Orr and Landis 1997). Campoletis sonorensis and transgenic plants also act synergistically and decrease survival of $H$. virescens larvae beyond the level expected of an additive interaction (Johnson and Gould 1992). Helicoverpa-resistant chickpeas showed no adverse effects on the survival and development of the host-specific parasitoid, C. chlorideae. However, the developmental period of C. chlorideae was prolonged and survival reduced when the insect host, $H$. armigera larvae were fed on $B$-treated chickpeas. This prolonged developmental period might be because of poor nutritional quality of the host larvaeand, reduced parasitoid survival due to early mortality of $H$. armigera larvae. Reduced cocoon formation and adult emergence, and prolonged larval period of C. chlorideae have been observed on $H$. armigera larvae fed on artificial diets containing the Bt toxins Cryl Ab and Cryl Ac (Sharma et al. 2008). Sublethal doses of $B t$ toxins may also reduce the nutritional quality of the insect host, which has been shown to result in negative effects on the development and survival of some natural enemies (Nordlund et al. 1988; Murugan et al. 2000). Cryl Ab and Cry2A intoxicated larvae of Spodoptera littoralis (Boisduval) result in same adverse effects on Chrysoperla carnea (Stephens) (Hilbeck et al. 1999; Dutton et al. 2002, 2003). Ingestion of $B t$ toxins decreases the concentrations of essential amino acids such as isoleucine, leucine, methionine, threonine, and valine in the haemolymph of S. littoralis (Salama et al. 1983), and these amino acids are also important for the development of $C$. carnea larvae (Yazlovetzky 2001). Decrease in amounts of some essential amino acids might be one of the possible mechanisms by which Bt-intoxicated $H$. armigera larvae might have affected the parasitoid, C. chlorideae. 
The exposure of $C$. chlorideae adults to $B t$ toxins in $10 \%$ honey reduced adult longevity and fecundity, which might be because of exposure to other Bt toxins/spores than to CrylAb or CrylAc or poor feeding due to other ingredients present in the $B t$ formulation, as no adverse effects of $B t$ were observed on the progenies. Although $H$. armigera fed on chickpea plants treated with $B t$ showed some negative effects on fitness and survival of $C$. chlorideae, these effects were largely indirect and host mediated (poor quality or early mortality of the host larvae), since no $B t$ toxin protein was detected in any of the life stages of $C$. chlorideae reared on $H$. armigera larvae fed on $B t$-sprayed chickpeas, and the adults fed on Bt-contaminated honey. In addition, there were no carryover adverse effects of $B t$ on the development, survival and progeny production of $C$. chlorideae in the following generation. Moreover, C. chlorideae exposure to $B t$ through $B t$-treated chickpea-fed $H$. armigera larvae resulted in increased cocoon formation, adult emergence, and the fecundity in the following generation, which might be because of selection of the most vigorous parasitoids from the $B t$ exposed generation. These studies have generated useful information on compatibility of $H$. armigera-resistant chickpea genotypes, Bt sprays, and the parasitoid, C. chlorideae per se, and the protocols for testing nontarget effects of Bt-transgenic chickpeas on natural enemies for developing appropriate strategies for deployment of Bt-transgenic chickpeas for controlling H. armigera.

\section{Acknowledgements}

The technical support of ICRISAT entomology staff during the studies, funding by Swiss Agency for Development and Cooperation (SDC), Berne, Switzerland, and the Department of Biotechnology (DBT), New Delhi, India, and IndoSwiss Collaboration on Biotechnology (ISCB), and the helpful comments by two anonymous referees on the manuscript are gratefully acknowledged.

\section{References}

Armes NJ, Bond GS, Cooters RJ, 1992. The laboratory culture and development of Helicoverpa armigera. Natural Resources Institute Bulletin No. 57. NRI, Chatham, UK.

Barbosa P, Saunders JA, Kemper J, Trumble R, Olechno J, Martinat P, 1986. Plant allelochemicals and insect parasitoids: effects of nicotine on Cotesia congregata and Hyposoter annulipes. J. Chem. Ecol. 12, 1319-1328.
Bhatnagar VS, Lateef SS, Sithanantham S, Pawar CS, Reed W, 1982. Research on Heliothis at ICRISAT. In: Proceedings of the International Workshop on Heliothis Management, 15-20 November 1981. Ed. by Reed W, Kumble V, International Crops Research Institute for the Semi-Arid Tropics (ICRISAT), Patancheru, Andhra Pradesh, India, 385-395.

Chandrashekar K, Kumari A, Kalia V, Gujar GT, 2005. Baseline susceptibility of the American bollworm, Helicoverpa armigera (Hübner) to Bacillus thuringiensis Berl. var. kurstaki and its endotoxins in India. Curr. Sci. 88, 167-175.

Danks HV, Rabb RL, Southern PS, 1979. Biology of insect parasites of Heliothis larvae in North Carolina. J. Georgia Entomol. Soc. 14, 36-64.

Dhillon MK, Sharma HC, 2007. Alternatives with Helicoverpa armigera Ichneumon wasp, Campoletis chlorideae in agro-ecosystems with $B t$ transgenic crops. J. Appl. Entomol. 131, 179-185.

Dhillon MK, Sharma HC, 2009a. Impact of Bt-engineered cotton on target and nontarget arthropods, toxin flow through different trophic levels, and seedcotton yield. Karnataka J. Agril. Sci. (Spec. Issue) 22, 462-466.

Dhillon MK, Sharma HC, 2009b. Temperature influences the performance and effectiveness of field and laboratory strains of the ichneumonid parasitoid, Campoletis chlorideae. Biocontrol 54, 743-750.

Dutton A, Klein H, Romeis J, Bigler F, 2002. Uptake of $B t$-toxin by herbivores feeding on transgenic maize and consequences for the predator, Chrysoperla carnea. Ecol. Entomol. 27, 441-447.

Dutton A, Klein H, Romeis J, Bigler F, 2003. Preymediated effects of Bacillus thuringiensis spray on the predator, Chrysoperla carnea in maize. Biol. Contr. 26, 209-215.

Fitt GP, 2003. Deployment and impact of transgenic Bt cottons in Australia. In: The economic and environmental impacts of agbiotech: a global perspective. Ed. by Kalaitzandonakes NG, Kluwer Academic Press, New York, NY, USA, 141-164.

Food and Agriculture Organization (FAO), 2004. Production statistics. Food and Agriculture Organization, Rome, Italy.

GenStat, 2008. Introduction to GenStat for Windows ${ }^{\circledR}$ Genstat, 10th edn. Lawes Agricultural Trust, Rothamsted Experimental Station, UK.

Gujar GT, 2005. Heliothis/Helicoverpa resistance to Bacillus thuringiensis: management strategies. In: Heliothis/ Helicoverpa management: emerging trends and strategies for future research. Ed. by Sharma HC, Oxford IBH Publishing Co. Pvt. Ltd, New Delhi, India, 275287.

Hilbeck A, Moar WJ, Pusztai-Carey M, Filippini A, Bigler F, 1999. Prey-mediated effects of Cryl Ab toxin and protoxin and Cry 2A protoxin on the predator 
Chrysoperla carnea (Neuroptera: Chrysopideae). Entomol. Exp. Appl. 91, 305-316.

Hulse JH, 1991. Nature, composition and utilization of grain legumes. In: Uses of tropical legumes: Proceedings of a Consultants' Meeting, 27-30 March 1989. International Crops Research Institute for the SemiArid Tropics, Patancheru, Andhra Pradesh, India, 1127.

James C, 2007. Preview: global status of commercialized biotech/GM crops: 2007. ISAAA Briefs No. 36. International Service for the Acquisition of Agri-Biotech Applications (ISAAA), Ithaca, NY, USA.

Johnson MT, Gould R, 1992. Interaction of genetically engineered host plant resistance and natural enemies of Heliothis virescens (Lepidoptera: Noctuidae) in tobacco. Environ. Entomol. 21, 586-597.

Kumar N, Kumar A, Tripathi CPM, 1994. Functional response of Campoletis chlorideae Uchida (Hymenoptera: Ichneumonidae), a parasitoid of Heliothis armigera (Hubner) (Lepidoptera: Noctuidae) in an enclosed experimental system. Biol. Agric. Hort. 10, 287-295.

Lawo NC, Mahon RJ, Milner RJ, Sarmah BK, Higgins TJV, Romeis J, 2008. Effectiveness of Bacillus thuringiensis-transgenic chickpeas and the entomopathogenic fungus Metarhizium anisopliae in controlling Helicoverpa armigera (Lepidoptera: Noctuidae). Appl. Environ. Microbiol. 74, 4381-4389.

Majumder ND, 2009. All India coordinated research project on chickpea: a profile. Ed. by Singh NP, Indian Institute of Pulses Research (IIPR), Kanpur, Uttar Pradesh, India, http://www.iipr.res.in/aicrp_chickpea.htm.

Manjunath TM, Bhatnagar VS, Pawar CS, Sitanatham S, 1989. Economic importance of Heliothis spp. in India and an assessment of their natural enemies and host plants. In: Proceedings of the Workshop on Biological Control of Heliothis: Increasing the Effectiveness of Natural Enemies, November 1985, New Delhi, India. Ed. by King EG, Jackson RD, Far Eastern Regional Research Office, US Department of Agriculture, New Delhi, India, 196-278.

McPhee KE, Croser J, Sarmah B, Ali SS, Amla DV, Rajesh PN, Zhang HB, Higgins TJ, 2007. Development of transgenics in chickpea. In: Chickpea breeding and management. Ed. by Yadav SS, Redden RJ, Chen W, Sharma B, CAB International, New Delhi, India, 458473.

Murugan K, Senthil KN, Jeyabalan D, Senthil NS, Sivaramakrishnan S, Swamiappan M, 2000. Influence of Helicoverpa armigera (Hubner) diet on its parasitoid Campoletis chlorideae Uchida. Insect Sci. Appl. 20, 23-31.

Nordlund DA, Lewis WJ, Altieri MA, 1988. Influences of plant produced allelochemicals on the host/prey selection behaviour of entomophagous insects. In: Novel aspects of insect-plant interactions. Ed. by Barbosa P,
Letourneau, John Wiley \& Sons, New York, NY, USA, 65-78.

Orr DB, Landis DA, 1997. Oviposition of European corn borer (Lepidoptera: Pyralidae) and impact of natural enemy populations in transgenic versus isogenic corn. J. Econ. Entomol. 90, 905-909.

Ramirez-Romero R, Bernal JS, Chaufaux J, Kaiser L, 2008. Impact assessment of Bt-maize on a moth parasitoid, Cotesia marginiventris (Hymenoptera: Braconidae), via host exposure to purified Cryl Ab protein or Bt-plants. Crop Prot. 26, 953-962.

Romeis J, Meissle M, Bigler F, 2006. Transgenic crops expressing Bacillus thuringiensis toxins and biological control. Nat. Biotechnol. 24, 63-71.

Salama HS, Sharaby A, Ragaei M, 1983. Chemical changes in the haemolymph of Spodoptera littoralis (Lep.: Noctuidae) as affected by Bacillus thuringiensis. Entomophaga 28, 331-337.

Sanyal I, Singh AK, Kaushik MA, Amla DV, 2005. Agrobacterium-mediated transformation of chickpea (Cicer arietinum L.) with Bacillus thuringiensis Cryl Ac gene for resistance against pod borer insect Helicoverpa armigera. Plant Sci. 168, 1135-1146.

Sharma HC (ed.), 2005. Heliothis/Helicoverpa management: emerging trends and strategies for future research. Oxford \& IBH Publishing Co. Pvt. Ltd, New Delhi, India.

Sharma HC, Pampapathy G, Dhillon MK, Ridsdill-Smith TJ, 2005a. Detached leaf assay to screen chickpeas for resistance to pod borer, Helicoverpa armigera. J. Econ. Entomol. 98, 568-576.

Sharma KK, Ananda Kumar P, Singh NP, Sharma HC, 2005b. Insecticidal genes and their potential in developing transgenic crops for resistance to Heliothis/Helicoverpa. In: Heliothis/Helicoverpa management: emerging trends and strategies for future research. Ed. by Sharma HC, Oxford \& IBH Publishing Co. Pvt. Ltd, New Delhi, India, 255-274.

Sharma HC, Arora R, Pampapathy G, 2007. Influence of transgenic cottons with Bacillus thuringiensis crylAc gene on the natural enemies of Helicoverpa armigera. Biocontrol 52, 469-489.

Sharma HC, Dhillon MK, Arora R, 2008. Effects of Bacillus thuringiensis $\delta$-endotoxin-fed Helicoverpa armigera on the survival and development of the parasitoid Campoletis chlorideae. Entomol. Exp. Appl. 126, 1-8.

Starks KJ, Burton RL, 1977. Greenbugs: a comparison of mobility on resistant and susceptible varieties of four small grains. Environ. Entomol. 6, 331-332.

Starks KJ, Muniappan R, Eikenbary RD, 1972. Interaction between plant resistance and parasitism against the greenbug on barley and sorghum. Ann. Entomol. Soc. Am. 65, 650-655.

Vinson SB, Barbosa P, 1987. Interrelationships of nutritional ecology of parasitoids. In: Nutritional ecology of 
insects, mites, spiders and related invertebrates. Ed. by Slansky F Jr, Rodriguez JG, John Wiley \& Sons, New York, NY, USA, 673-695.

Vojtech E, Meissle M, Poppy GM, 2005. Effects of Bt maize on the herbivore Spodoptera littoralis (Lepidoptera: Noctuidae) and the parasitoid Cotesia marginiventris (Hymenoptera: Braconidae). Trans. Res. 14, 133144.

Wilson WD, Flint HM, Deaton RW, Fischhoff DA, Perlak FJ, Armstrong TA, Fuchs RL, Berberich SA, Parks NJ, Stapp BR, 1992. Resistance of cotton lines containing a Bacillus thuringiensis toxin to pink bollworm (Lepidop- tera: Gelechiidae) and other insects. J. Econ. Entomol. 85, 1516-1521.

Yan ZG, Wang CZ, 2006. Similar attractiveness of maize volatiles induced by Helicoverpa armigera and Pseudaletia separata to the generalist parasitoid Campoletis chlorideae. Entomol. Exp. Appl. 118, 87-96.

Yazlovetzky IG, 2001. Features of the nutrition of Chrysoperla larvae and larval artificial diets. In: Lacewings in the crop environment. Ed. by McEwen P, New TR, Whittington AF, Cambridge University Press, Cambridge, UK, 320-337. 
Copyright of Journal of Applied Entomology is the property of Wiley-Blackwell and its content may not be copied or emailed to multiple sites or posted to a listserv without the copyright holder's express written permission. However, users may print, download, or email articles for individual use. 